\title{
FT-Raman spectroscopy for the differentiation between cutaneous melanoma and pigmented nevus ${ }^{1}$
}

\author{
Espectroscopia FT-Raman na diferenciação entre melanoma cutâneo e nevo pigmentado
}

\author{
Sidney Bandeira Cartaxo', Ivan Dunshee de Abranches Oliveira Santos ${ }^{\mathrm{II}}$, Renata Bitar ${ }^{\mathrm{III}}$, Andréa Fernandes Oliveira', \\ Lydia Masako Ferreira $^{I V}$, Herculano Silva Martinhov ${ }^{\text {, Airton Abrahão Martin }}{ }^{\mathrm{VI}}$ \\ ${ }^{\text {I}}$ Fellow Master degree, Post-Graduate Program in Plastic Surgery, UNIFESP, São Paulo, Brazil. \\ ${ }^{\text {II }}$ PhD, Head of Plastic Surgery Division, Department of Surgery, UNIFESP, São Paulo, Brazil. \\ III Fellow PhD degree, Post-Graduate Program in Plastic Surgery, UNIFESP, São Paulo, Brazil. \\ ${ }^{\text {IV }}$ PhD, Full Professor, Plastic Surgery Division and Chairwoman of Department of Surgery, UNIFESP, São Paulo, Brazil. \\ ${ }^{\vee} \mathrm{PhD}$, Head of Center for Human and Natural Sciences (CCNH), UFABC, Santo André-SP, Brazil.

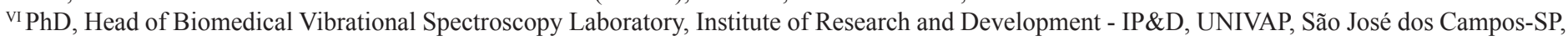 \\ Brazil.
}

\begin{abstract}
Cutaneous melanoma is the most aggressive type of skin cancer and Ft-Raman spectroscopy has been studied as a potential method that could be a real alternative for early diagnosis of neoplasms. Purpose: To qualify the spectral FT-Raman data, in order to differentiate cutaneous melanoma and pigmented nevus. Methods: For this study, 10 samples of cutaneous melanoma, 9 samples of pigmented nevi, and 10 samples of normal skin were obtained by incisional biopsies performed during plastic surgeries ex vivo, immediately after removing the surgical sample. Results: The FT-Raman spectra of each group presented a high correlation between the elements of the same group, thus favoring the elaboration of spectral averages. When analyzing the spectral standard of each group, the normal skin standard did not show a significant variation between the spectra; the standard of the pigmented nevi group showed significant variation, and the cutaneous melanoma group also showed variation. Through univariate analysis, specific bands were detected for each vibrational mode identified. The discriminatory analysis of the data showed a $75.3 \%$ efficiency of the differentiation between the three groups studied. Conclusion: The vibrational modes Polysaccharides, Tyrosine and Amide-I differentiated the melanoma from the pigmented nevus.
\end{abstract}

Key words: Melanoma. Spectrum Analysis, Raman. Nevus, Pigmented. Biopsy.

\section{RESUMO}

O melanoma cutâneo é o câncer de pele mais agressivo, e a espectroscopia FT-Raman tem sido estudada como um método em potencial que pode ser uma verdadeira alternativa no diagnóstico precoce de neoplasias. Objetivo: Qualificar os dados espectrais FT-Raman de modo a diferenciar melanoma cutâneo de nevo pigmentado. Métodos: Foram utilizadas 10 amostras de melanoma cutâneo, obtidas por meio de biopsias incisionais realizadas "ex-vivo"; nove amostras de nevo pigmentado e 10 amostras de pele normal foram coletadas durante cirurgias plásticas. Resultados: Os espectros FT-Raman de cada grupo diagnóstico apresentaram alta correlação entre os elementos do mesmo grupo, o que favoreceu a realização das médias espectrais. Analisando o padrão espectral de cada grupo, o de pele normal não mostrou grande variação entre os espectros; o de nevo pigmentado apresentou variação notável e, o grupo melanoma primário também indicou variação. Por meio de análise univariada foram identificadas bandas específicas para cada modo vibracional identificado. A análise discriminante aos dados mostrou $75,3 \%$ de eficiência na diferenciação entre os três grupos estudados. Conclusão: Os modos vibracionais Polissacarídeos (Banda I), Tirosina (Banda 6) e Amida I (Banda 10) diferenciaram o melanoma do nevo pigmentado. Descritores: Melanoma. Análise Espectral Raman. Nevo Pigmentado. Biópsia.

${ }^{1}$ Research performed at Plastic Surgery Division, Post-Graduation Program of Plastic Surgery, Department of Surgery, Federal University of São Paulo (UNIFESP), Brazil.

\section{Introduction}

The cutaneous melanoma is a malignant tumor originating in the skin melanocytes. It is the most aggressive skin cancer. Its global incidence continues increasing in an alarming way. The earlier this neoplasm is diagnosed, the higher probability of a cure. The need for non-invasive diagnostic methods for the detection of melanomas in their early stages led to the appearance of several new techniques such as dermatoscopy, high frequency ultrasonography of the skin, fluorescence spectroscopy. However, 
a non-invasive methodology for the detection of cutaneous melanoma was not yet devised ${ }^{1,2}$. Clinical difficulty with the diagnosis of the melanoma still persists.

An excisional biopsy, with histopathological examination, is the golden standard for the diagnosis of this neoplasm. However, a conventional biopsy is an invasive procedure, and takes some time to be analyzed, meaning that it cannot be done in real time, Furthermore, as it is a morphologic examination, the analysis of a lesion can sometimes, even if seldom, lead to discordant results among pathologists.

In this research, an optic biopsy technique for the study of oncological lesions was used, FT-Raman spectroscopy, a method which supplies information on the molecular structure of the sample under examination ${ }^{3-5}$.

This technique has specific characteristics, appropriate for the study of the skin, both in vivo and in vitro. Raman spectroscopy provides detailed information on the composition and molecular structures of the skin. However, as molecular vibrations are influenced directly by the micro-environment of the functional groups, vibrational aspects supply information on molecular interactivity. Also, this type of information can be obtained in a completely non-invasive manner, as the Raman spectrum is collected directly over the $\operatorname{skin}^{6,7}$.

Biopsies of several skin lesions showed that they produced unique spectral variations on examination, distinguishing them from the normal skin control. With these results, it was suggested that FT-Raman spectroscopy could make the difference as a diagnostic tool in dermatology ${ }^{6,7}$. Other skin neoplasms, such as squamou cell carcinoma, were diagnosed by this method.

The purpose of this study was to qualify the spectral FT-Raman data, in order to differentiate cutaneous melanoma and pigmented nevus.

\section{Methods}

The samples of cutaneous melanoma were collected only from lesions with a diameter of over $2 \mathrm{~cm}$, nodular or ulcerated, corresponding to the vertical growing phase, with elevated Breslow rates.

For this study were collected 10 samples of cutaneous melanoma, nine of pigmented nevi, and 10 samples of normal skin, obtained by incisional biopsy performed during "ex-vivo" plastic surgeries, meaning immediately after removing the surgical item. The samples were immediately frozen in liquid nitrogen. First they were kept, still frozen, at the Melanoma Bank of the Federal University of São Paulo (UNIFESP) São Paulo Medical School (EPM) during up to four months, and afterwards, still frozen in liquid nitrogen, taken to the Vibracional Biomedical Spectroscopy Lab (LEVB) of the Research and Development Institute of the University of the Paraiba Valley (UNIVAP).

The principal surgical item was submitted to routine histopathological examination. The samples of the three groups were thawed in a $0.9 \%$ physiological solution. Each sample was divided in 3, 4 or 5 fractions of $2 \mathrm{~mm}$ each.

A Bruker ${ }^{\circledR}$ RFS 100 FT-Raman spectrometer was used with a Nd:YAG $1064 \mathrm{~nm}$ laser as excitation source. 250 Sweepings were applied to all samples, with a power of $300 \mathrm{~mW}$ and spectral resolution of $4 \mathrm{~cm}^{-1}$. There were five collection points per sample $\mathrm{e}^{8}$.
All in all, 105 spectra of normal tissue, 140 of neoplastic and 126 of pigmented nevi were collected.

To analyze the Raman spectra, first they were preprocessed by correcting the base line and performing the vector normalization using the Minitab software (Minitab® 15.1.1.0).

Once established all data bases, we investigated the variables obtained from specific samples and their capacity to differentiate the groups from a statistical point of view. At first, the model of variance analysis with a constant factor was used, and this demonstrated that all variables showed an association with their own group.

The next phase of the statistical study was the employment of a discriminating analysis, the results of which showed a significant differentiation between the three groups under study.

After the measurement, the samples were fixed in a $10 \%$ solution of formalin, and thereafter sent to the Pathological Anatomy Department of the UNIFESP/EPM, for diagnostic confirmation. At this phase, the samples were regularly processed for the confection of histological slides, colored with Hematoxilin and Eosin (HE). The slides were read and their structural characteristics analyzed, in agreement with the standards established by Clark et al. ${ }^{9}$. Thus, each spectrum obtained could be related to a confirmed histological finding, enabling the formation of spectral groups allowing the development of univariate and multivariate analyses.

\section{Results}

First, graphics based on the spectra of each studied group, Normal Skin, Pigmented Nevus and Primary Melanoma were elaborated.

The graphic, showing the averages and percentages 25 and 75 of the spectra represented in Figure 1, refers to the Normal Skin Group. For the elaboration of this graphic, 105 spectra from 10 patients were used. All samples were histologically diagnosed as normal skin. Relating the average of the spectra to their dispersion, it can be noted there is no significant variation between the spectra of this group.

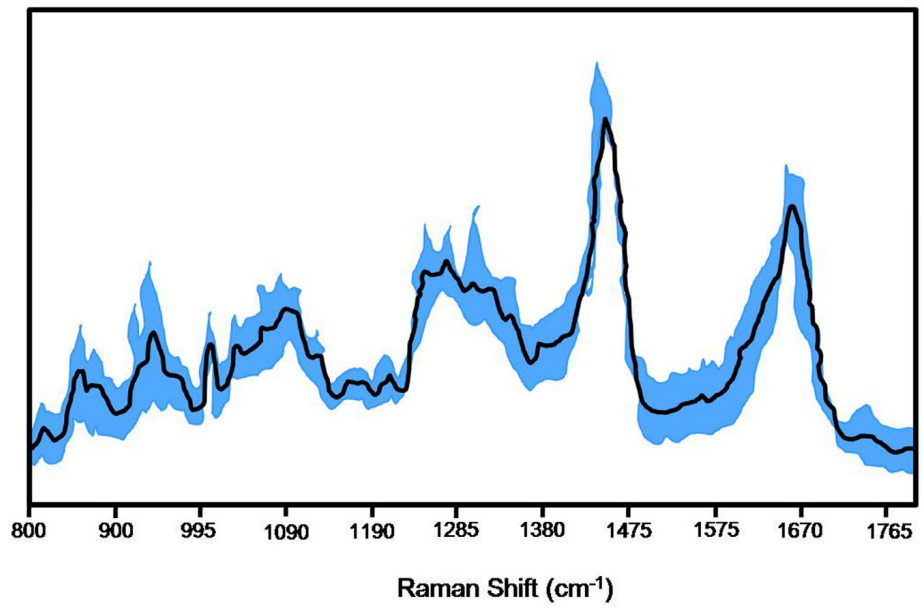

FIGURE 1 - Graphic of the averages and percentages 25 and 75 of 105 Raman spectra of the Normal Skin group 
The same procedure was repeated for the Pigmented Nevi group, where 126 spectra from 9 patients were used. Differently from the former group, The Pigmented Nevus group included several tissue types such as: Composed Melanocytic Nevus (1 patient, 15 spectra), Intradermal Melanocytic Nevus (5 patients, 75 spectra), Cellular Intradermal Nevus (2 patients, 30 spectra) and Pigmented Fibroepithelial Polyp (1 patient, 7 spectra). For the elaboration of the graphic of the averages and percentages 25 and 75 of these variables, in order to characterize the spectra of the Pigmented Nevi group, it was suggested to use all data, independently from their histological variety (Figure 2).

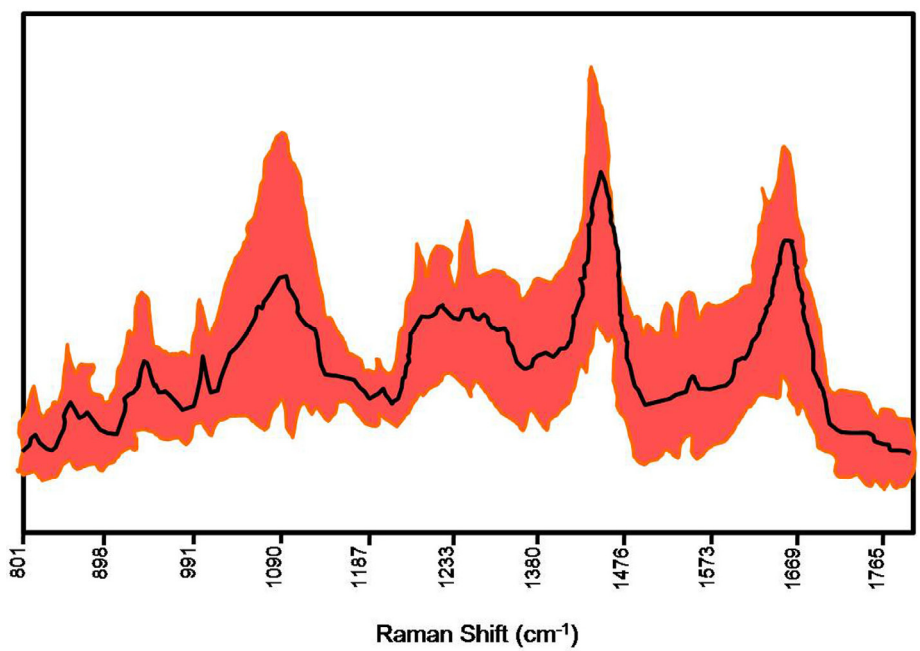

FIGURE 2 - Graphic of the averages and percentages 25 and 75 of 126 Raman spectra of the Pigmented Nevus group

When observing figure 3 of the graphic of averages and percentages of the Primary Melanoma group, one notices the existence of spectral variation which, as for the Pigmented Nevus group, is insignificant. The differences of this pathology among the patients selected to compose this group, may be one of the factors contributing to this variation. As with the group of Pigmented Nevus, these differences will be discussed later with the exposition of new graphics and tables.

\section{Univariate analysis}

To elaborate the statistical analysis of the spectral data, the spectra were divided in agreement with their histological group,
When observing Figure 2 of the graphic of averages and percentages 25 and 75 of the Pigmented Nevus group, a significant spectral variation in this group can be noticed, due to its great histological variety. The differences visually identified in this figure were later discussed with the exposition of new graphics and tables facilitating comprehension of the spectral information found.

The third group, Primary Malanoma, was exclusively composed by spectra obtained from samples histologically evaluated as primary nodular cutaneous melanoma. These samples were collected from 10 patients, resulting in 140 Raman spectra (Figure 3).

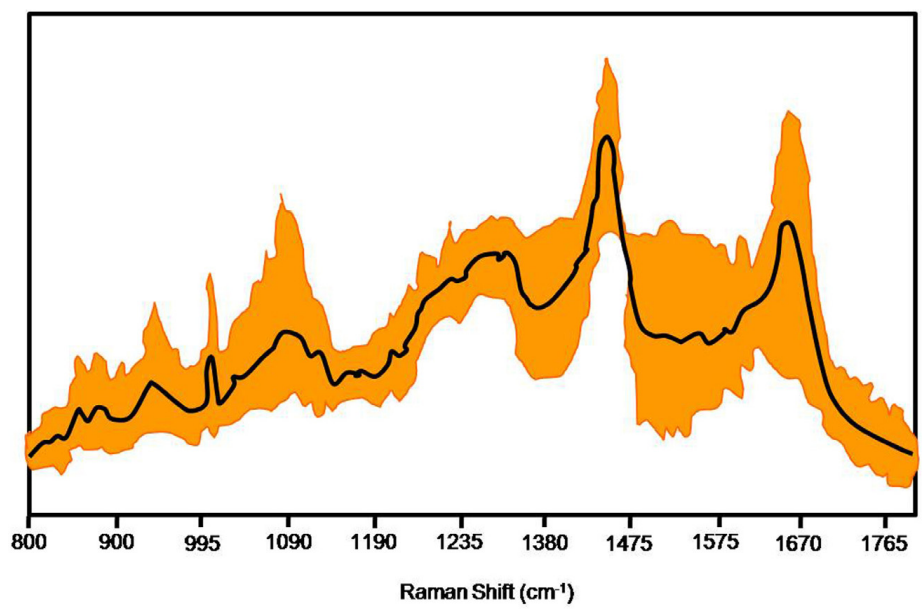

FIGURE 3 - Graphic of the averages and percentages 25 and 75 of 140 Raman spectra of the Primary Melanoma group

being: Normal Skin, Pigmented Nevus and Primary Melanoma. Within each of these groups, the spectra were put together in sample units. Then, a few variables, mainly those being practical for the classification of the groups from statistical point of view, were investigated. To find these variables, this study took into account the information on the biochemical compounds present in the biological tissues, using their identification by Raman spectra.

With the analysis of the averages and percentages 25 and 75 graphics of each diagnostic group (Figures 1, 2 and 3) the specific bands of each known vibrational mode were identified. This identification was based on the research of Gniadecka, modified for this study by the inclusion of new bands ${ }^{8}$. See the results in Table 1.

TABLE 1 - Vibrational modes and Biomolecules related to the spectra of Normal Skin, Pigmented Nevus and Primary Melanoma

\begin{tabular}{|c|c|c|c|c|}
\hline \multirow[b]{2}{*}{ Bands } & \multicolumn{3}{|c|}{ Group } & \multirow[b]{2}{*}{ Biomolecules } \\
\hline & $\begin{array}{l}\text { Normal Skin } \\
\quad\left(\mathrm{cm}^{-1}\right)\end{array}$ & $\begin{array}{l}\text { Nevus } \\
\left(\mathrm{cm}^{-1}\right)\end{array}$ & $\begin{array}{l}\text { Melanoma } \\
\left(\mathrm{cm}^{-1}\right)\end{array}$ & \\
\hline 1 & 813,876 & 832,867 & 807,955 & Polysaccharides \\
\hline 2 & 921,957 & 923,961 & 934,984 & Amino acids, Valine and Proline \\
\hline 3 & 1004 & 1004 & 1004 & Phenylalanine (ring) \\
\hline 4 & 1033,1125 & 1033,1125 & 1032,1121 & PO2, nucleic acids \\
\hline 5 & 1160,1206 & 1162,1200 & 1158,1221 & Tyrosine \\
\hline 6 & 1247,1343 & 1247,1343 & 1235,1341 & Lipids, Proteins, Amide-III \\
\hline 7 & 1312,1384 & 1322,1380 & 1316,1341 & Adenine and Phenylalanine (Melanine) \\
\hline 8 & 1451,1544 & 1397,1555 & 1407,1526 & Proteins and Lipids \\
\hline 9 & 1619 & 1613 & 1582,1621 & DNA (adenine, guanine, phenylalanine melanine) \\
\hline 10 & 1663,1748 & 1657,1750 & 1663 & Lipids e Amide-I (Proteins) \\
\hline
\end{tabular}


Following the identification of the biochemical bands relevant to statistical analyses, the first step was the employment of the variance analysis model with a constant factor, revealing that all variables, or Raman vibrational modes, presented a significant association with each diagnostic group.

In order to better understand these results, Boxplot graphics were elaborated for each vibrational mode analyzed (Bands 1 to 10, described in Table 1); they clearly showed the distribution of those biomolecules within each group studied.

This set of figures, where the qualitative description of all vibrational modes was resumed, shows that the spectra of the Melanoma group were those obtaining the greatest intra-group difference for all analyzed items, followed by the groups of pigmented nevus and normal skin, in this order. It is likely that this fact refers to the significant fluorescence generated by the tissue due to its high degree of pigmentation.

Finally, for each vibrational mode presented so far, the descriptive level favoring the second phase of this analysis, the multivariate analysis of the spectra, was calculated. These results may be observed in Table 2 .

TABLE 2 - Results of the comparison between the groups (Normal Skin, Pigmented Nevus and Primary Melanoma) as related to each of the variables composing the study

\begin{tabular}{ccc}
\hline Bands & Variable & Descriptive level \\
\hline 1 & POLYSACCHARIDES & 0,000294 \\
2 & Amino acids, Valine and Proline & 0,000366 \\
3 & Phenylalanine & 0,000327 \\
4 & $\mathrm{PO}_{2}$, nucleic acids & 0,000477 \\
5 & TYROSINE & 0,000441 \\
6 & Lipids, Proteins, Amide-III & 0,000467 \\
7 & Adenine and Phenylalanine & 0,000576 \\
8 & Proteins and Lipids & 0,000592 \\
9 & DNA & 0,000611 \\
10 & AMIDE I & 0,000639 \\
\hline
\end{tabular}

In the discriminating analysis the results of which presented significant differentiations between the three groups studied, the following variables deserve attention: Polysaccharides (Figure 4), Tyrosine (Figure 5) and Amide-I (Figure 6).

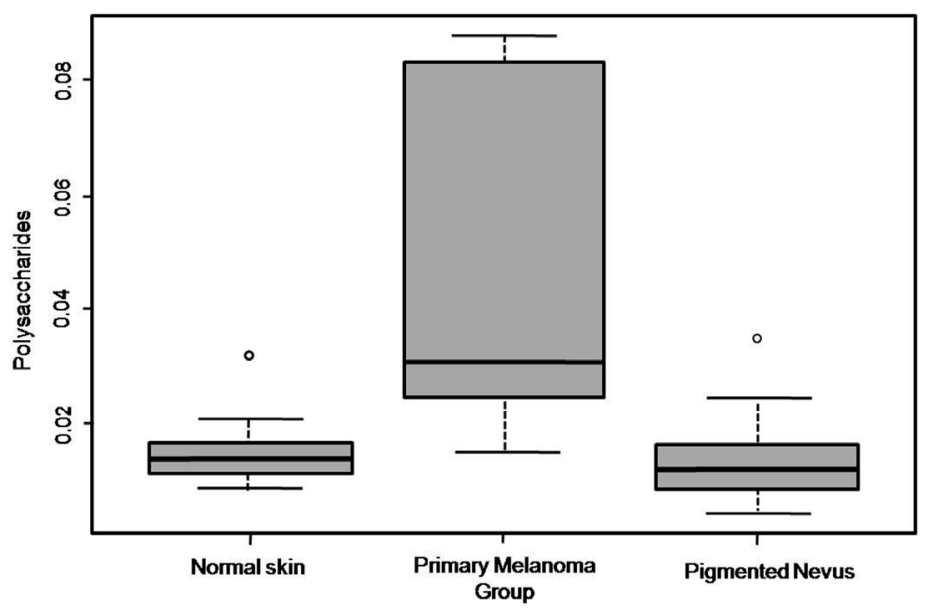

FIGURE 4 - Distribution of the Polysaccharide variable

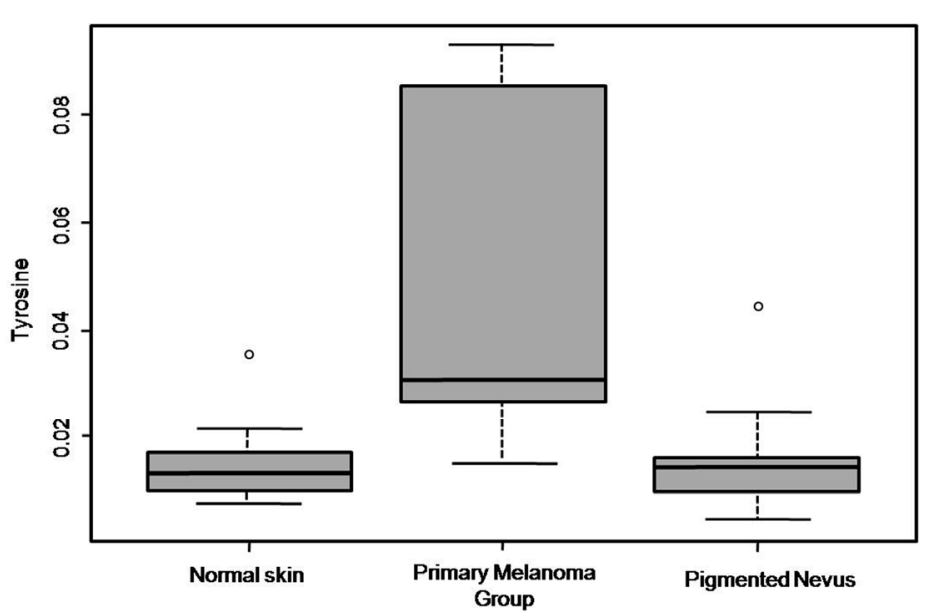

FIGURE 5 - Distribution of the Tyrosine variable

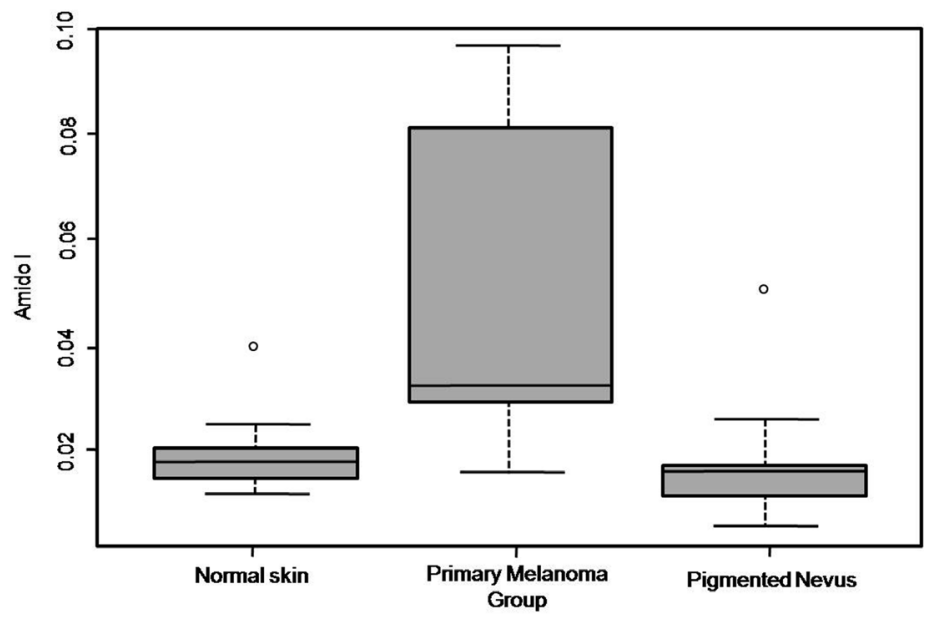

FIGURE 6 - Distribution of the Amide-I variable

The variables Polysaccharides, Tyrosine and Amide-I stood out at the differentiation of the three groups, in agreement with the classification functions detailed as follows (Tables 3 and 4).

TABLE 3 - Coefficients of the discriminating functions

\begin{tabular}{ccc}
\hline Variables & Function 1 & Function 2 \\
\hline Polysaccharides & 9,096 & $-0,418$ \\
Tyrosine & $-13,321$ & 5,828 \\
Amide-I & 4,651 & $-4,607$ \\
\hline
\end{tabular}


TABLE 4 - Coefficients of the classification functions

\begin{tabular}{cccc}
\hline \multirow{2}{*}{ Variables } & \multicolumn{3}{c}{ GROUP } \\
\cline { 2 - 4 } & Normal Skin & Primary Melanoma & Pigmented Nevus \\
\hline Polysaccharídes & $-67,430$ & $-72,372$ & $-104,267$ \\
Tyrosine & 101,130 & 126,423 & 160,732 \\
Amide-I & $-53,732$ & $-73,782$ & $-81,343$ \\
Constant & $-36,402$ & $-31,979$ & $-52,565$ \\
\hline
\end{tabular}

Based on the results of the discriminating functions, a graphic of the dispersion of these functions was elaborated, in order to visualize these values. Figure 7 represents the graphic elaborated based on the correlation of the vibrational modes of Polysaccharides, Tyrosine and Amide-I.

It can be observed, also, that the sample units were separated with a $75.3 \%$ efficiency, being the variables of normal skin presented in blue, the pigmented nevus in green, and the primary melanoma in red.

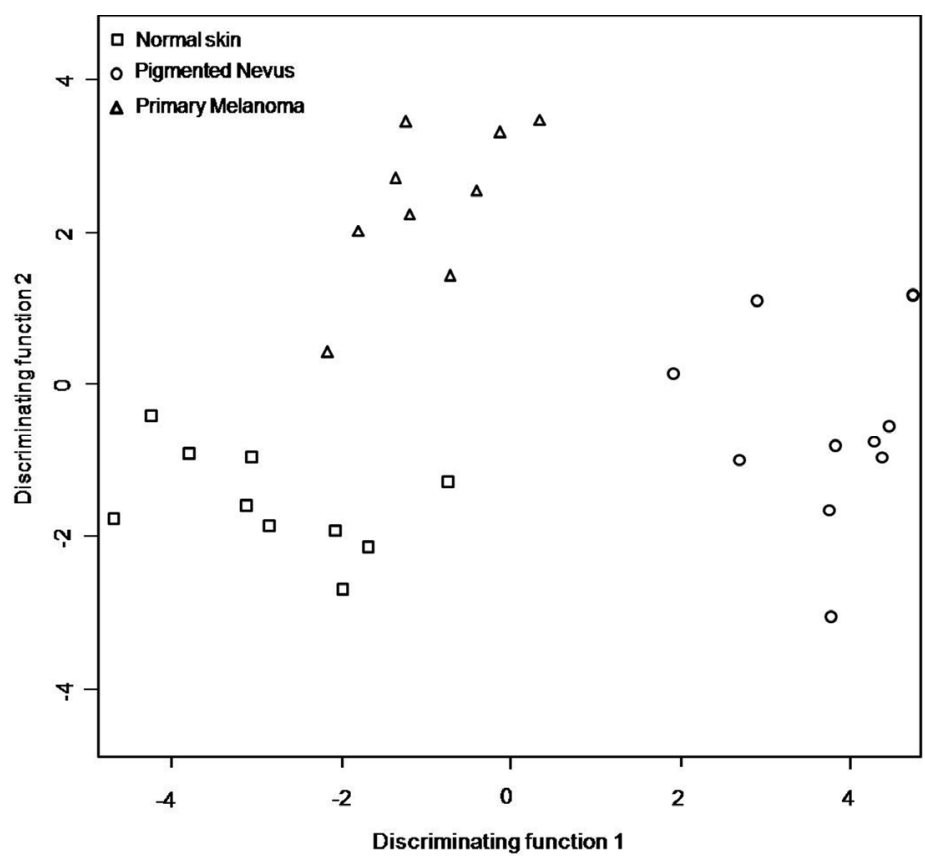

FIGURE 7 - Differentiation of the groups by means of the two discriminating functions obtained

\section{Discussion}

The literature research that applied to this study was developed by Gniadecka et al. ${ }^{7}$, where spectra from pigmented benign and malign cutaneous lesions were compared: seborrheic keratose, pigmented nevus, pigmented basal cell carcinoma and melanoma. By means of visual analysis of the spectra, the authors were able to differentiate the lesions, and, using the neural system, the sensibility of melanoma diagnosis was $85 \%$ and the specificity was $99 \%$. However, they did not discuss the difficulty in obtaining spectra referring to fluorescence, nor comment the pre-processing of the spectral data, neither false-positive and false-negative results. On the other hand, a few of the Raman spectra of these samples, totally obscured by a strong fluorescence, participated of the data analysis, even though they were called outliers ${ }^{7}$.

Pre-processing of the data is an extremely important phase in order to guarantee reproducibility and reliability of the spectral data analysis. Due to the extreme irregularity of the study samples' surface, even when improving this irregularity with a samplecarrying device, it is always necessary to adjust the signals. The base-line serves to eliminate fluorescence and the vectorial normalization serves to adequate the intensities.

The present study designates as total intensity normalization the method of vectorial normalization. Concluding, when applying the method of total intensity normalization, after the required correction of the base line, the calibration models obtained were strong in all analyzed spectra. This study enhanced the findings of present practical experience. Therefore this study proceeded using the method of pre-processing here described ${ }^{10}$.

Significant differences were found in the region between $800-980 \mathrm{~cm}^{-1}$ (Figure 2). However, different of the other regions, in this energy interval the intensity of the vibrational modes of pigmented nevus and primary melanoma was less than with normal tissues. The same effect was observed before by Gniadecka et al. ${ }^{7}$.

The bands of 855 and $937 \mathrm{~cm}^{-1}$ are typical characteristics of the collagen spectrum and are due to the proline vibration and to the $\mathrm{C}-\mathrm{C}$ stretching vibration in the protein structure ${ }^{11}$.

In present study, in the regions of Raman shifts $1540-1620 \mathrm{~cm}^{-1}$ and $1040-1100 \mathrm{~cm}^{-1}$, corresponding to DNA's vibrational mode, an increase of spectral intensity was observed in primary melanoma. This intensity gain of the primary melanoma spectrum in these bands could be related to an increase in nucleic acids and protein synthesis in malignant tissues, due to an elevated quantity of mitoses and, consequently, increased duplication of genetic material, responsible for the proliferation of malignant cells. The same effect was observed by Morris et al. ${ }^{12}$, who did studies on molecular biology and energy transformation in DNA of cancerous and pre-cancerous tissues, using Raman spectroscopy.

As may be observed in Figures 2, 3 and 4, the vibration band of the secondary protein structure (Amide-I) is located at $1600-1700 \mathrm{~cm}^{-1}$, corresponding to the stretching vibration mode of the connections $\mathrm{C}=\mathrm{O}$. The vibration mode of the same peptic connection (Amide-III) is at $1222-1362 \mathrm{~cm}^{-1}$, designated by the vibration of the connections of $\mathrm{N}-\mathrm{H}$ and stretching of the connection C-N. The peak referring to Amide-I $\left(1640-1680 \mathrm{~cm}^{-1}\right)$ also appeared stronger in malignant tissues, which helps with the identification of this type of tissues. With the present results, the intensity gain of this peak can be observed in the region of the smallest energy of this band, being 1540 to $1600 \mathrm{~cm}^{-1}{ }^{13}$. In this same study it was noted that the spectral region of 1540 to $1570 \mathrm{~cm}^{-1}$ corresponds to the bands of the nucleotide bases Guanine and Adenine ${ }^{12}$. The major change occurring with 
neoplastic tissues is the increase in nucleic acids contents of the cells. Hence, this can be related to the increase in intensity of these peaks in malignant tissues, in the results here presented. The transformation of the amide bands in the Raman spectrum were attributed to the changes in the configuration of the proteins ${ }^{2}$. In the primary melanoma group of present study, the alterations examined visually were similar, and the region of amide-I presented increased intensity.

In principle, these intensity differences in a few bands can be exploited to differentiate between Raman spectra of normal tissue, of pigmented nevus and of cutaneous melanoma. It is also clear that many of these changes reflect alterations of the secondary structure of the proteins. As all stages of the illness are caused by fundamental changes in the biochemistry of the cells and/or tissues, and as those alterations can be detected by Raman spectra, the changes in the intensity of the vibrational bands are, this way, directly related to the biochemical changes of the tissues ${ }^{4,12,13}$.

The structure of the lipids is represented by the vibration of $\mathrm{CH} 2$ in the region between $1420-1500 \mathrm{~cm}^{-1}$. These peaks are rather complex, depending on factors such as, for instance, hydrogen connections, that can altered due to tumor growth and its demands ${ }^{11,14}$.

\section{Conclusion}

The FT-Raman spectral data were qualified and the variables: Polysaccharides, Tyrosine and Amide-I enabled the differentiation between cutaneous melanoma and pigmented nevus.

\section{References}

1. Harland M, Mistry S, Bishop DT, Bishop JA. A deep intronic mutation in CDKN2A is associated with disease in a subset of melanoma pedigrees. Hum Mol Genet. 2001;10(23):2679-86.

2. Mahadevan-Jansen A, Mitchell MF, Ramanujam N, Malpica A, Thomsen S, Utzinger U, Richards-Kortum R. Near-infrared Raman spectroscopy for in vitro detection of cervical precancers. Photochem Photobiol. 1998;68(1):123-32.
3. Williams AC, Barry BW, Edwards HG, Farwell DW. A critical comparison of some Raman spectroscopic techniques for studies of human stratum corneum. Pharm Res. 1993;10(11):1642-7.

4. Hanlon EB, Manoharan R, Koo TW, Shafer KE, Motz JT, Fitzmaurice M, Kramer JR, Itzkan I, Dasari RR, Feld MS. Prospects for in vivo Raman spectroscopy. Phys Med Biol. 2000;45(2):R1-59.

5. Teixeira CS, Bitar RA, Martinho HS, Santos AB, Kulcsar MA, Friguglietti CU, da Costa RB, Arisawa EA, Martin AA. Thyroid tissue analysis through Raman spectroscopy. Analyst. 2009;134(11):2361-70.

6. Nijssen A, Maquelin K, Santos LF, Caspers PJ, Bakker Schut TC, den Hollander JC, Neumann MH, Puppels GJ. Discriminating basal cell carcinoma from perilesional skin using high wave-number Raman spectroscopy. J Biomed Opt. 2007;12(3):034004.

7. Gniadecka M, Wulf HC, Nielsen OF, Christensen DH, Hercogova J. Distinctive molecular abnormalities in benign and malignant skin lesions: studies by Raman spectroscopy. Photochem Photobiol. 1997;66(4):418-23. 8. Gniadecka M, Philipsen PA, Sigurdsson S, Wessel S, Nielsen OF, Christensen DH, Hercogova J, Rossen K, Thomsen HK, Gniadecki R, Hansen LK, Wulf HC. Melanoma diagnosis by Raman spectroscopy and neural networks: structure alterations in proteins and lipids in intact cancer tissue. J Invest Dermatol. 2004;122(2):443-9.

9. Clark WH Jr, Elder DE, Guerry D 4th, Epstein MN, Greene MH, Van Horn M. A study of tumor progression: the precursor lesions of superficial spreading and nodular melanoma. Hum Pathol. 1984;15(12):1147-65.

10. Afseth NK, Segtnan VH, Wold JP. Raman spectra of biological samples: A study of preprocessing methods. Appl Spectrosc. 2006;60(12):1358-67.

11. Oliveira AP, Bitar RA, Silveira L, Zângaro RA, Martin AA. Near-infrared Raman spectroscopy for oral carcinoma diagnosis. Photomed Laser Surg. 2006;24(3):348-53.

12. Morris MD, Berger A, Mahadevan-Jansen A. Infrared and Raman spectroscopy. J Biomed Opt. 2005;10(3):031101.

13. Krafft C, Steiner G, Beleites C, Salzer R. Disease recognition by infrared and Raman spectroscopy. J Biophotonics. 2009;2(1-2):13-28.

14. Moncada B, Sahagún-Sánchez LK, Torres-Alvarez B, CastanedoCázares JP, Martínez-Ramírez JD, González FJ. Molecular structure and concentration of melanin in the stratum corneum of patients with melasma. Photodermatol Photoimmunol Photomed. 2009;25(3):159-60.

\section{Acknowledgment}

Authors would like to thank Vale do Paraíba University (UNIVAP).

\section{Correspondence:}

Sidney Bandeira Cartaxo

Division of Plastic Surgery, Department of Surgery

Federal University of São Paulo

Rua Napoleão de Barros, 715/4 ${ }^{\circ}$ andar

04024-0022 São Paulo - SP Brazil

Phone: (55 11) 5576-4118

sidney.cartaxo@uol.com.br

Conflict of interest: none Financial source: FAPESP

Received: January 12, 2010

Review: March 17, 2010

Accepted: April 14, 2010

\section{How to cite this article}

Cartaxo SB, Santos IDAO, Bitar R, Oliveira AF, Ferreira LM, Martinho HS, Martin AA. FT-Raman spectroscopy for the differentiation between cutaneous melanoma and pigmented nevus. Acta Cir Bras. [serial on the Internet] 2010 July-Aug;25(4). Available from URL: http://www.scielo.br/acb 